Didaché: Journal of Christian Education

Vol. 2, No. 2 (2021): 145-159

e-ISSN: 2722-8584

Published by: Sekolah Tinggi Teologi Simpson Ungaran

DOI: $10.46445 /$ djce.v2i2.433

\title{
Qualitative Analysis of Christian Religious Education Teacher Contextual Learning Strategies in Online Learning
}

\author{
Dian Paskarina1, Ludwig Beethoven Jones Noya², Pratiwi Eunike ${ }^{3}$, Bobby \\ Kurnia Putrawan 4 \\ 1Sekolah Tinggi Teologi Indonesia, Jakarta, Indonesia \\ ${ }^{2}$ Vanderbilt University, Nashville, United State of America \\ ${ }^{3}$ Sekolah Tinggi Teologi Indonesia, Jakarta, Indonesia \\ ${ }^{4}$ Sekolah Tinggi Teologi Moriah, Tangerang, Indonesia \\ Email: bkputrawan@gmail.com
}

\begin{abstract}
In the era of the Covid-19 pandemic, distance or online learning has become the primary method used by the government, in this case the Ministry of Education and Culture, to prevent the increasing number of Covid-19 viruses and the emergence of clusters in schools. In online learning, PAK teachers in their multifunctional role need to apply contextual learning strategies so that teaching and learning activities can take place in a systematic, directed, unobstructed, effective and efficient manner and can achieve educational targets. Contextual learning is a learning strategy that emphasizes the process of student involvement to achieve goals associated with real-life situations. The method used in this research is descriptive qualitative and data collection is done by interview and documentation as well as relevant literature. The results of the study on some high achieving students' motivation and interest in learning increased with the online learning method after the Christian Religious Education teacher carried out the role optimally by using contextual learning strategies.
\end{abstract}

Keywords: Christian education role teacher, contextual strategic learning, online learning

\begin{abstract}
Abstrak
Di era pandemi covid 19 pembelajaran jarak jauh atau daring merupakan metode yang digunakan pemerintah dalam hal ini Kemendikbud sebagai upaya untuk mencegah semakin meningkatnya pandemi covid 19 dan munculnya klaster di sekolah sehingga metode daring menjadi satu-satunya pilihan untuk pembelajaran yang harus dilakukan di era pandemi covid 19. Strategi pembelajaran merupakan garis-garis besar haluan untuk mencapai tujuan pembelajaran. Pada pembelajaran daring maka guru PAK dalam peran multifungsinya perlu menerapkan strategi pembelajaran kontekstual agar kegiatan belajar mengajar dapat berlangsung secara sistematis, terarah, tidak terhambat, efektif dan efisien serta dapat mencapai sasaran. Pembelajaran kontekstual merupakan
\end{abstract}

D. Paskarina, et. al., Qualitative Analysis of Christian Religious Education Teacher.... 
strategi pembelajaran yang menekankan pada proses keterlibatan siswa untuk mencapai sasaran dihubungkan dengan kondisi situasi kehidupan yang nyata. Metode yang digunakan pada penelitian ini adalah kualitatif deskriptif dengan pendekatan studi kasus. Pengumpulan data dilakukan dengan wawancara serta dokumentasi juga literatur-literatur yang relevan. Hasil penelitian pada beberapa siswa berprestasi motivasi dan minat belajar meningkat dengan metode belajar daring setelah guru Pendidikan Agama Kristen menjalankan peran secara maksimal dengan menggunakan strategi pembelajaran kontekstual.

Kata kunci: guru PAK; strategi pembelajaran kontekstual; belajar daring

\begin{tabular}{lll}
\hline Article History Received: Augst. 1, $2021 \quad$ Revised: Nov. 2, 2021 & Accepted: Nov. 4, 2021 \\
This is an open access article under the CC BY-SA license cc) (-) &
\end{tabular}

\section{Introduction}

At the end of 2019, the world was shocked by the emergence of an outbreak of pneumonia in the city of Wuhan, Hubei province, China. On January 7,2020 , researchers managed to identify the cause of the pneumonia as a novel coronavirus and the WHO officially named this disease COVID 19 or Corona Virus Disease 19 and the name of the virus was SARS-CoV-2 or Severe acute respiratory syndrome corona virus (Thevarajan, H.O. Nguyen, \& All., 2020; Wu, Chen, \& Chan, 2020). The spread of this virus continued to increase significantly and spread throughout the world until March 11, 2020, when WHO declared Covid-19 a pandemic (Cucinotta \& Vanelli, 2020). Transmission of the virus occurs through droplets and aerosols, making this virus highly contagious, which is why the Indonesian government is dealing with the transmission of the Covid 19 virus implements a process called 5M. As a result of the pandemic, the education system underwent changes in structure and methods, including in learning to prevent an increase in COVID cases, especially since the COVID-19 virus has mutated with new variants, including the variant with the highest transmission, namely Delta.

As a result of the virus, Indonesia has implemented health protocol policies that have impacted on the educational system based on Circular 4 of 2020 regarding the implementation of educational policies in the emergency period of the spread of the virus. As a result, the Ministry of Education and Culture makes a decision that all educational institutions must carry out an online teaching and learning process (Menteri Pendidikan dan Kebudayaan Republik Indonesia, 2020). 
The problem is that not all students are ready with the online method. At elementary school age in particular, there are many obstacles faced in the learning process. The impact of these obstacles makes students' motivation and interest in learning decrease, even though it is known that the learning objectives as defined include to creating a learning atmosphere and learning process so that students actively develop their potential to have religious spiritual strength, selfcontrol, intelligent personality, noble character, and skills needed for themselves, society, nation and state (Sutrisno, Putrawan, Hutabarat, \& Bulan, 2021; UndangUndang Republik Indonesia, 2003). In a Christian educational setting, education includes spiritual power, namely educating for change associated with responsibility and faith in the form of worship (Nicholas, 2010:4). Education also aims to turn students into disciples of Christ who have integrity, Christ-like character and are able to integrate faith into various aspects of life, including in the learning process (Sutrisno, Hestiningrum, Lumingkewas, \& Putrawan, 2021; Sutrisno \& Hutabarat, 2019).

With the online method, many parents and students are not tech savvy. From the aspect of students, because they are still at the elementary school age, without guidance and direction they cannot learn optimally, as they are still children, aged between 7-12 years. At the age of 6-9 years, children enter the phase of concrete operations development where they can perform operations, and logical reasoning replaces intuitive thoughts as long as they are given concrete examples. At this stage, children's thinking is characterized by the principle of conversion of an object that remains the same even though it is transformed in a different way so that it is a concrete object that they can think logically about (Bujuri, 2018; Piaget, 1932).

The ages of 9-12 years is considered the "intellectual period" (Bujuri, 2018; Wati et al., 2017). At a time like this, students should receive effective, efficient learning, with realistic methods so that they are able to receive Christian Religious Education lessons. Although children in this age bracket are intellectually ready to accept demands and implement and complete learning demands, they need consistent guidance so that they are able to receive lessons. According to their age. In dealing with this problem, CRE teachers must explore their abilities by applying appropriate methods and strategies so that students can change their learning behavior and increase their interest and motivation in learning. The learning process is an urgent part of education and teachers are required to have the ability to translate educational goals through facilities, 
infrastructure, methods, strategies and provide direction to the teaching and learning process (Caesari, Amelia, Hasanah, Putra, \& Rahman, 2013; Purnomo, 2017).

So based on the explanation above, this article has the goal of exploring how CRE teachers can best use contextual learning strategies in online learning methods. CRE teachers are multifunctional: in addition to being responsible for carrying out their roles as teachers in general, they must also be able to translate the Christian life through the teaching and learning process, including in generating interest and motivation to learn and forming the characters of students which will improve student achievement.

\section{Method}

This article utilizes a descriptive qualitative research methodology, in particular a case study. The research was carried out in three stages, namely: (1) the pre-field stage, (2) the field stage, and (3) the post-field stage. This research was conducted at State Elementary School (SDN) 01 grades 6A and 6B, Pondok Bambu, East Jakarta in the 2020/2021 Academic Year. The key instrument of this research is the researcher himself. Data collection in qualitative research is done with primary data and secondary data (Herdiansyah, 2010). The primary data were taken through virtual interviews. Sources of data were 3 students of class $6 \mathrm{~A}$ and 2 students of class 6B, each of which was obtained by purposive sampling.

In this study, the researcher used in-depth interviews with the aim of collecting data or information with the aim of getting a complete picture of the topic being investigated (Irianto \& Bungin, 2001; Mukhtar, 2013; Sugiyono, 2018). The primary data were taken through virtual interviews. Sources of data were 3 students of class $6 \mathrm{~A}$ and 2 students of class $6 \mathrm{~B}$, each of which was obtained by purposive sampling. In this study, the researcher used in-depth interviews with the aim of collecting data or information with the aim of getting a complete picture of the topic being investigated (Irianto \& Bungin, 2001; Lexy J. Moleong, 2006; Mukhtar, 2013). Secondary data is taken through assessment documents and learning tools such as lesson plans (syllabi).

In analyzing the data, the researcher used a data analysis framework that was adapted from an interactive model. There are three stages of data analysis carried out, namely: (1) the stage of data reduction (data reduction), (2) the stage of data exposure (data display), and (3) the stage of drawing conclusions and 
verifying data (conclusion drawing and verification). The technique of checking the validity of the data is carried out by several techniques, namely credibility test, transferability test, dependability test and confirmability test.

\section{Result and Discussion}

\section{Result}

The world of education during the pandemic is increasingly showing instability in the face-to-face learning process. Meanwhile, in providing good educational services to students, it must be supported by normal situations or normal learning. The success of good learning is only the responsibility not only of a teacher who carries out teaching and learning activities, but is also determined by the joint commitment of the principal and other school members in determining the policies to be implemented.

There are several government policies that were implemented at the school level during the pandemic; particularly the restrictions on learning in schools and online learning. Online learning is still carried out flexibly according to the agreement of each class. In this context, CRE teachers are required to provide lessons and assignments according to the online learning schedule and are fully responsible for the successful implementation of KBM in CRE subjects. Then the CRE teacher reports the results of the implementation of online learning activities to the principal on a regular basis (once every week on Monday).

The learning method is a method used by teachers in order to implement lesson plans designed to achieve educational goals used by teachers to present material to students (Diana \& Rofiki, 2020; Hermawan, 2020; Ulfa \& Saifuddin, 2018). In choosing a learning method the teacher uses the following methods: 1 ) the objectives to be achieved in learning, 2) inquiry, 3) questioning, 4) learning communication, 5) modeling or exemplary, 6) reflection, and 7) evaluation (authentic assessment).

This section focuses on data collected from three observations in grades $6 \mathrm{~A}$ and $6 \mathrm{~B}$ through checklist observations and field notes. In this case, the researcher will describe the activities that occur in the classroom. In this study, the researcher was a non-participant. The author of this paper will describe the data obtained from three observations at once in one description.

The results of the research on the application of the steps of the contextual model in Christian Religious Education learning are as follows: first, the 
application of constructivism steps has been carried out by the teacher well. This can be seen from the activities of teacher in the classroom who have taken to constructing CRE materials steps based on indicators that have been validated. The teacher explained the learning objectives at the beginning of the lesson before entering the learning material to be studied. After the teacher explains the learning objectives, the teacher guides students to work and find their own knowledge about learning Christian religious education through student books; then the teacher guided students to develop thinking, carry out meaningful and memorable learning activities and construct knowledge and skills that students have just discovered about descriptive texts.

Second, the teacher has done well in applying the steps to find (inquiry) locate and evaluate information about any topic. This can be seen from the activities of teacher in the classroom who have taken steps to find (inquiry) based on indicators that have been validated. In the inquiry step, the teacher assigns students to observe the pictures of giving and helping actions that have been shared by the teacher to find and collect data. After students find the data, students are guided by the teacher to carry out the process of transferring observations into an understanding of the images of giving and helping actions that have been observed by students.

Third, the application of the questioning step has been carried out by the teacher well. This can be seen from the teacher's activities in the classroom who have taken the questioning step based on the indicators that have been validated. In this step the teacher asks students to find out how much students understand about the act of giving and helping that is being studied. After knowing how much students understand about the act of giving and helping, the teacher provides stimulation or motivation to students to increase students' curiosity about the act of giving and helping.

Fourth, the implementation of the learning community steps has been carried out by the teacher well. This can be seen from the activities of teacher in the classroom who have taken steps for a learning community based on indicators that have been validated. In the learning community step the teacher divides students into 2 groups. After the teacher divides students into groups, the teacher assigns students to discuss about the objects contained in the pictures that have been observed by the teacher. Students and teachers assign students to work together. 
Fifth, the application of the modeling step has been carried out by the teacher well. This can be seen from the activities of teachers in the classroom who have carried out modeling steps based on validated indicators. In this modeling step the teacher gives an example to students how the act of giving and helping is based on seeing the object in the picture that has been shared by the teacher.

Sixth, the application of the reflection steps carried out by the teacher has not been carried out properly. This can be seen from the teacher activities in the classroom who did not carry out the reflection step perfectly based on the validated indicators. In this step the teacher should assign students to do presentation activities and carry out summary writing activities independently of the knowledge that students get about giving and helping.

Seventh, the implementation of the actual assessment steps (authentic assessment) has been carried out by the teacher well. This can be seen from the activities of teachers in the classroom who have carried out the actual assessment steps (authentic assessment) based on validated indicators. In this step the teacher is seen conducting direct assessment activities of students' speaking and attitude skills in front of the class and assessing student assignments, namely the results of student writing about giving and helping in CRE.

\section{Barriers to Online Learning}

Based on the research result, there are three obstacles faced by teachers in implementing online learning on CRE subjects at Sekolah Dasar Negeri (SDN) 01 grades 6A and 6B, Pondok Bambu, East Jakarta, as follows:

First, in class 6A there were 3 (three) outstanding students and before the pandemic they showed very good achievements in terms of knowledge, skills, and spiritual aspects. Since online learning they have shown a decrease in achievement because 1 (one) student is the eldest child, at home there are 2 (two) younger siblings who also study online. Only one cellphone is used interchangeably with his two younger siblings. Parents' backgrounds as motorcycle taxi drivers often have difficulty buying internet quota because they are more concerned with paying for house contracts and daily meals.

Meanwhile, 2 (two) other students experienced the same difficulties because their parents had insufficient income so they had to find it difficult to buy internet quota, although school fees in the country were free, their income was insufficient causing constraints in buying internet quota. In addition, the 
background of parents is such that they are not technologically savvy and their education levels are only up through elementary school.

Second, the problems in class $6 \mathrm{~B}$ are not much different from the problems in class 6A. Before the pandemic and distance learning there were 2 (two) outstanding students; but since online learning their achievements have decreased sharply. The first student can't study online because both parents work, and bring his cellphones with them. Only after the parents come home from work can the child use their parents' cellphones to do homework.

The problem with the second student in this class is that their parents' educational attainment is too low, to the point that they cannot teach the material given by the school. The problem is the same for class 6A where parents fully rely on the teacher because the parents' educational background is inadequate to help children learn or work on the homework given by the teacher. In the cases faced by 5 outstanding students in grades $6 \mathrm{~A}$ and $6 \mathrm{~B}$, the role of the $\mathrm{CRE}$ teacher in setting contextual learning strategies as such: the method of constructivism, inquiry, questioning, learning communication, modeling (exemplary), as well as reflection and evaluation in online learning was very helpful. After 1 month, there was a consistent increase in the achievement of the five students and other friends in grades 6A and 6B, which was proven, for example, firstly, students can understand and do obedient and helpful actions to parents and the accuracy of entering online classes.

\section{Discussion}

The contextual learning model is able to be utilized to improve the ability to understand Christian religious education. First, the contextual learning model is able to improve the ability to understand Christian religious education because it can increase student activity. These results can be seen from the learning steps of this model in which the teacher directs students to develop their thinking in carrying out learning activities and find answers. Research conducted (Gitriani, Aisah, Hendriana, \& Herdiman, 2018; Herdiansyah, 2010; Jayanti, Rohaeti, \& Sariningsih, 2018) states that contextual learning models can help students become active in developing reasoning. Research conducted by Ibrahim (2018) and Sugianto (2016) also states that the contextual learning model can improve students' mastery of concepts and literacy. In its application, students are guided by the teacher to find facts from a problem, so that it will provoke student reactions and develop curiosity so as to increase students' activeness and critical 
thinking. Research conducted by Asta, Agung and Widiana (2015) states that high student learning outcomes are proven to be obtained by students who have high critical thinking skills as well.

Second, contextual learning can improve the attitude of cooperation between students. Cooperation and respect are important in the learning process, because through these elements that students will collaborate and complement each other's knowledge. Pratiwi, Ardianti, Kanzunnudin (2018) state that the ability to cooperate is politely listening to others, interrupting politely, respecting other people's ideas, capturing other people's ideas appropriately before disagreeing, and supporting each group member's participation. The importance of the application of contextual learning models so that learning is conducive and collaborates among students can be seen through increasing understanding skills in problem solving in addition to using conventional learning models (Parhusip \& Hardini, 2020). Contextual learning models can provide meaningful learning because students' knowledge and experiences are associated with learning materials. Research conducted by Tanasyah \& Simanungkalit (2020) also states that peers will have an impact on student learning outcomes. The learning process becomes effective if the relationship between students is well established so that learning objectives can be achieved optimally (Comp. Ibrahim, 2018; Kadarwati \& Aswandi, 2015).

Third, contextual learning makes the learning atmosphere fun and comfortable for students. A comfortable learning atmosphere will have an impact on student learning motivation and make students enjoy learning so that it has an impact on student learning outcomes. The results of research conducted by Eunike \& Putrawan (2021) also state that a pleasant learning atmosphere will improve student learning outcomes because students absorb information more easily. Savitri, Santyasa, \& Rapi (2017) states that meaningful learning can be created with a pleasant learning atmosphere, as well as a pleasant atmosphere so that it will have an effect on increasing student learning outcomes. In addition, a pleasant learning atmosphere will increase students' high interest in learning. Students who have a high interest in learning will try to obtain optimal learning outcomes and in the learning process they can be active and enthusiastic in participating in all the activities being taught (Darling-Hammond, Flook, CookHarvey, Barron, \& Osher, 2020; Ibrahim, 2018; Parhusip \& Hardini, 2020).

Daring Teaching and Learning is a teaching strategy where the concept being studied is a real situation so that students understand the concept of 
learning and can see the connection with its use in everyday life (Abidah, Hidaayatullaah, Simamora, Fehabutar, \& Mutakinati, 2020; Hermanto, Arita Marini, Sumantri, \& Syarif, 2021; Purnomo, 2017). Contextual learning emphasizes the involvement of students to be able to understand and find the material being studied by connecting it to real life situations, thus encouraging students to have the ability to apply it in everyday life. In contextual learning, students do not just listen, record and repeat what is learned, but rather focuses on the process of how students can experience directly what is learned in its entirety so that it has an impact on development and change both cognitively, affectively, and psychomotorically.

Daring learning also directs students in an effort to build thinking skills and master the material so that they are able to analyze, think critically and constructively in developing intellectually and other aspects such as emotional and spiritual intelligence. As a learning model, it accommodates students' learning activities to seek, process and find concrete learning experiences through their involvement so that learning is not just a product affiliated with values alone, but rather a process. Contextual learning is also a learning concept that helps teachers in connecting between the material and the existing reality so that it will encourage students to apply the knowledge they have learned (Mutmainah \& Kamaluddin, 2021; Parhusip \& Hardini, 2020; Savitri et al., 2017).

Contextual learning provides many benefits during the COVID-19 pandemic where all learning is directed at online learning, and has quite interfering impacts and obstacles for the development of students' interests, motivation and learning behavior. Contextual learning is something that is constructive, innovative, and progressive towards the development of students' learning. Some benefits include: a) Contextual learning focuses on the learning process and how students can develop a deeper understanding of the material through direct experience in their current reality, so that students do not just stop accepting and go through the process of understanding the subject matter, but to apply it in life; b) Contextual learning does not only focus on the knowledge process but also the process of receiving, seeking, and finding material for students that is connected to real life. The material received, sought and found will be applied to lived experience directly, so that this will affect students' behavior and become a foundation for their futures (Savitri et al., 2017); c) Contextual learning in the context of Christian education will help CRE teachers see the uniqueness of each student. Basic to Christian belief is that every child is 
created uniquely; so, teachers who are given the authority and opportunity from God to format and influence students' minds with a mandate given from God with the gift of teaching can determine the relevant strategies for each particular student. CRE teachers not only arouse the interest of students, but guide and arrange learning activities in such a way that students are faced with God's demands for their lives (Nicholas, 2010); d) Strategy in learning means how teachers plan teaching activities or a plan for teaching. Therefore, when setting strategies, teachers must consider the objectives, nature of teaching materials, students studying, facilities or infrastructure and learning time (Caesari et al., 2013; Purnomo, 2017). In the context of the pandemic era with the problems faced by students in online learning, the contextual learning strategy of CRE teachers must include comprehensive cognitive, affective, and psychomotor objectives.

From the results of the study, by looking at the problems that exist in student learning at SDN 01, Pondok Bambu, East Jakarta, the teacher can determine the contextual learning strategy of constructivism, inquiry, questioning, learning communication, modeling (exemplary), as well as reflection and evaluation in the process of learning to teach online. Contextual learning strategies synergize with the role of CRE teachers as educators, mentors, and evangelists. In the case of their parents who do not have the ability to teach the subject matter, the teacher can visit the students twice a week, for example, to encourage, motivate, provide direction, and give solutions for each problem on their homework. In this case, CRE teachers also collaborate with other teachers whose subjects have a high level of difficulty such as physics, mathematics, science and other subjects. The teacher can visit students regularly while still implementing health protocols, especially for students who have problems in distance learning.

\section{Conclusion}

After the researchers made observations on the phenomena that occur in the teaching and learning process with the method of constructivism, inquiry, questioning, learning communication, modeling (exemplary), as well as reflection and evaluation, the researchers of this paper found that implementing these methods changed student learning behavior, besides interest and learning motivation also changing. This is evidenced from the first, the motivation of students is increasing, as evidenced by the fact that no one is late for class. Second, students' understanding of the CRE material on obedience and helping 
attitudes increased with an average score of 6.8 to 7.6. Third, information from parents that students are more obedient to parents' advice and help parents' activities. The impact on student achievement at SDN 01, Pondok Bambu, East Jakarta, has increased significantly. The problem with online education in this current moment occurs for various reasons; in general the unpreparedness of students and parents in conducting online or online learning. This is where the role of CRE teachers is to be able to carry out their duties and responsibilities in applying appropriate methods and strategies such as contextual learning strategies. An integrative contextual learning strategy deals with current lived experience so that students can develop cognitive, affective and psychomotor intelligence in a systematic way and apply it in an integrated faith life with the lessons taught in the teaching and learning process. The result is that interest and motivation and learning behavior change and have an impact on a significant increase in achievement.

\section{References}

Abidah, A., Hidaayatullaah, H. N., Simamora, R. M., Fehabutar, D., \& Mutakinati, L. (2020). The Impact of Covid-19 to Indonesian Education and Its Relation to the Philosophy of "Merdeka Belajar." Studies in Philosophy of Science and Education, 1(1), 38-49. https:/ / doi.org/10.46627/ sipose.v1i1.9

Asta, K. R., Agung, A. A. G., \& Widiana, I. W. (2015). Pengaruh Pendekatan Saintifik dan Kemampuan Berpikir Kritis terhadap Hasil Belajar. Jurnal PGSD Universitas Pendidikan Ganesha, 3(1), 1-10. https://doi.org/http://dx.doi.org/10.23887/jjpgsd.v3i1.563.

Bujuri, D. A. (2018). Analisis Perkembangan Kognitif Anak Usia Dasar dan Implikasinya dalam Kegiatan Belajar Mengajar. LITERASI (Jurnal Ilmu Pendidikan), 9(1), 37. https:/ / doi.org/10.21927/literasi.2018.9(1).37-50

Caesari, B. D., Amelia, A., Hasanah, U., Putra, A. M., \& Rahman, H. (2013). Analisis Keefektifan Pembelajaran Online di Masa Pandemi Covid-19. MAHAGURU: Jurnal Pendidikan Guru Sekolah Dasar, 1(2), 28-37. Retrieved from https:/ / ummaspul.e-journal.id/MGR/article/view/559

Cucinotta, D., \& Vanelli, M. (2020). WHO declares COVID-19 a pandemic. Acta Biomedica, 91(1), 157-160. https:/ / doi.org/10.23750/abm.v91i1.9397

Darling-Hammond, L., Flook, L., Cook-Harvey, C., Barron, B., \& Osher, D. (2020). Implications for educational practice of the science of learning and development. Applied Developmental Science, 24(2), 97-140. 
https:/ / doi.org/10.1080/10888691.2018.1537791

Diana, E., \& Rofiki, M. (2020). Analisis Metode Pembelajaran Efektif di Era New Normal. Jurnal Review Pendidikan Dan Pengajaran, 3(2), 336-342. https:// doi.org/10.31004/jrpp.v3i2.1356.

Eunike, P., \& Putrawan, B. K. (2021). Kajian Pedagogis Guru Pendidikan Agama Kristen Terhadap Motivasi Belajar Siswa Di Era Pandemi Covid 19 : Studi Kasus Siswa Smk Harapan Bagi Bangsa, Jakarta Utara. 6(1), 32-44. https:// doi.org/https:/ / doi.org/10.46307/rfidei.v6i1.83

Gitriani, R., Aisah, S., Hendriana, H., \& Herdiman, I. (2018). Pengembangan Lembar Kerja Siswa Berbasis Pendekatan Kontekstual pada Materi Lingkaran Untuk Siswa SMP. Jurnal Review Pembelajaran Matematika, 3(1), 40-48. https:// doi.org/10.15642/jrpm.2018.3.1.40-48

Herdiansyah, H. (2010). Metode Penelitian Kualitatif untuk Ilmu-ilmu Sosial. Jakarta: Salemba Humanika.

Hermanto, Arita Marini, Sumantri, \& Syarif, M. (2021). Studi Kebijakan Kepala Sekolah Dalam Pembelajaran Daring Bagi Siswa Sekolah Dasar di Era New Normal Pada Masa Pandemik Covid-19. Jurnal Basicedu, 5(2), 1060-1066. https:// doi.org/https://doi.org/10.31004/basicedu.v5i3.936

Hermawan, I. (2020). E-Learning Berbasis Virtual classroom di Era Covid-19. Hawari: Jurnal Pendidikan Agama Dan Keagamaan Islam, 1(1), 1-10. Retrieved from https://journal.unsika.ac.id/index.php/hawari/article/view/3929

Ibrahim, H. (2018). Implementasi Strategi Pembelajaran Kontekstual Dalam Pembentukan Karakter Peserta Didik Di Smp Negeri 2 Pinrang. AL-ISHLAH: Jurnal Pendidikan Islam, 76(1), 74. https:// doi.org/10.35905/alishlah.v16i1.735

Irianto, H., \& Bungin, B. (2001). Pokok-Pokok Penting Tentang Wawancara. In Metode Penelitan Kualitatif. Jakarta: PT. Raja Grafindo Persada.

Jayanti, K., Rohaeti, E. E., \& Sariningsih, R. (2018). Efektifitas Lembar Kegiatan Siswa Berbasis Pendekatan Problem Solving Pada Materi Perbandingan Senilai Untuk Siswa Smp. Jurnal Pendidikan Tambusai, 2(6), 1755-1761.

Kadarwati, D. A. A., \& Aswandi. (2015). The Implementation of Contextual Teaching and Learning to Teach Writing Procedure Text. Retain, 3(1), 1-7. Retrieved from

https:// ejournal.unesa.ac.id/index.php/retain/article/view/10740/

Lexy J. Moleong. (2006). Metode penelitian Kualitatif. Bandung: Remaja Rosda Karya. 
Menteri Pendidikan dan Kebudayaan Republik Indonesia. Pelaksanaan Kebijakan Pendidikan Dalam Masa Darurat Penyebaran Co Ro Naviru S D/Sease (Covid- 1 9). , (2020).

Mukhtar. (2013). Metode Praktis Penelitian Deskriptif Kualitatif. Jakarta: GP Press Group.

Mutmainah, D., \& Kamaluddin. (2021). Peran Guru Pendidikan Pancasila dan Kewarganegaraan sebagai. 1(1), 12-17.

Nicholas, W. S. P. (2010). Mendidik Untuk Kehidupan. Surabya: Momentum.

Parhusip, Y. P., \& Hardini, A. T. A. (2020). Meta Analisis Efektivitas Pembelajaran

Kontekstual Terhadap Kemampuan Pemahaman Matematika Bagi Siswa

Sekolah Dasar. Jurnal Mimbar Ilmu, 25(3), 319-326.

https:// doi.org/http:/ / dx.doi.org/10.23887/mi.v25i3.27954

Piaget, J. (1932). Thee Moral Judgment Of The Child, Hegar Paul. London: Trench, Trubner and Co.

Pratiwi, I. A., Ardianti, S. D., \& Kanzunnudin, M. (2018). Peningkatan Kemampuan Kerjasama Melalui Model Project Based Learning (PjBL) Berbantuan Metode Edutainment Pada Mata Pelajaran Ilmu Pengetahuan Sosial. Refleksi Edukatika: Jurnal Ilmiah Kependidikan, 8(2). https:/ / doi.org/10.24176/re.v8i2.2357

Purnomo, B. (2017). Analisis Strategi Guru Dalam Pelaksanaan Pengelolaan

Kelas Di Sekolah Dasar. Jurnal Gentala Pendidikan Dasar, 2(2), 237-255. https:// doi.org/10.22437/gentala.v2i2.6809

Savitri, Santyasa, I. W., \& Rapi, N. K. (2017). Analisis Kualitatif Strategi Pembelajaran Guru Fisika: Relevansinya Dalam Pengembangan Motivasi Berprestasi Dan Self-Efficacy Siswa (Online). Jurnal Matematika, Sains, Dan Pembelajarannya, 11(2), 107-124.

Sugianto, H. (2016). Penerapan Model Kontekstual Berbantuan Multimedia Untuk Meningkatkan Penguasaan Konsep Dan Literasi Sains Siswa Pada Materi Fluida Di Sma Kelas Xi Ipa. Jurnal Penelitian Pendidikan, 14(1), 1-7. https:// doi.org/10.17509/jpp.v14i1.3207

Sugiyono. (2018). Metode Penelitian Kuantitatif, Kualitatif, dan RED. Bandung: Alfabeta.

Sutrisno, Hestiningrum, P., Lumingkewas, M. S., \& Putrawan, B. K. (2021). Christian Religious Education Toward The Teenagers Character Building. Evangelikal: Jurnal Teologi Injili Dan Pembinaan Warga Jemaat, 5(2), 202-212. https:// doi.org/https:/ / doi.org/10.46445/ejti.v5i2.330 
Sutrisno, \& Hutabarat, C. (2019). Orang Tua dan Teman Bermain terhadap Perkembangan Sosial Anak. QUAERENS: Journal of Theology and Christianity Studies, $1(1)$, 28-55. https:// doi.org/https:// doi.org/10.46362/quaerens.v1i1.15

Sutrisno, S., Putrawan, B. K., Hutabarat, C., \& Bulan, S. E. (2021). Penerapan Nilai Karakter Bagi Kaum Proletar Usia Remaja di Yayasan Kemah Kasih. Abdi: Jurnal Pengabdian Dan Pemberdayaan Masyarakat, 3(2), 189-199. https:// doi.org/10.24036/abdi.v3i2.123

Tanasyah, Y., \& Simanungkalit, L. N. (2020). Perumpamaan Sebagai Model Pembelajaran Yang Efektif Untuk Proses Belajar Mengajar Pendidikan Kristen. Quaerens, 2(1), 30-43. https://doi.org/10.46362/quaerens.v2i1.18

Thevarajan, I., H.O. Nguyen, T., \& All., E. (2020). Breadth of concomitant immune responses prior to patient recovery: a case report of non serve COVID 19. Nature Medicine, 26(4), 453-455. https:/ / doi.org/10.1038/s41591-020-0819-2 Ulfa, M., \& Saifuddin. (2018). Terampil Memilih Dan Menggunakan Metode Pembelajaran. Suhuf, 30(1), 35-56.

Undang-Undang Republik Indonesia. Sistem Pendidikan Nasional. , (2003).

Wati, L. R., Putri, R., Ariani, D., Hidayah, N., Reksohusodo, S., \& Silvani, Y. (2017). Factors Related to the Need of Sexuality Education in Primary School in Gondanglegi Sub-District, Malang Regency. Journal Of Issues In Midwifery, 1(1), 1-18. https:/ / doi.org/10.21776/ub.JOIM.2017.001.01.1

Wu, Y. C., Chen, C. S., \& Chan, Y. J. (2020). The outbreak of COVID-19: An overview. Journal of the Chinese Medical Association, 83(3), 217-220. https:// doi.org/10.1097/JCMA.0000000000000270 